\title{
Rozhovor s Adamem Gamoranem o pedagogickém výzkumu, jeho financování a vztahu ke vzdělávací politice
}

\author{
David Greger, Jaroslava Simonová
}

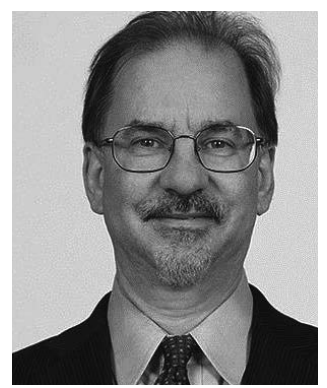

Profesor Adam Gamoran je významným americkým sociologem vzdělávání, byl poradcem vlády Baracka Obamy a působí jako prezident nadace Williama T. Granta. Orbis scholae číslo 3/2016 ho podrobněji představil a uvedl první díl rozhovoru, který s ním vedli David Greger (DG) a Jaroslava Simonová (JS). Tato část se zabývala testováním žáků, různými formami diferenciace ve vzdělávání, volbou školy a dalšími otázkami vzdělávací politiky. Nyní přinášime část rozhovoru, která se týkala pedagogického výzkumu v USA, jeho vztahu k politickému rozhodování i jeho financováním.

\section{Národní akademie věd a Národní výzkumná rada}

DG: V první části našeho rozhovoru jsme mluvili o různých programech $v$ oblasti vzdělávací politiky a dotkli jsme se vztahu mezi tvorbou zákonů a pedagogickým výzkumem. Jedním z významných aktérů v této oblasti je Národní výzkumná rada. Můžete českým čtenářům přibližit, o jaký typ organizace se jedná a jak přispívá ke vztahu mezi výzkumem a politickým rozhodováním?

AG: Národní výzkumná rada (National Research Council, NRC) je výzkumnou sekcí Národních akademií přírodních, technických a lékařských věd. Národní akademie věd (National Academy of Sciences, NAS) byla založena již prezidentem Lincolnem, aby americkému národu poskytovala informace a rady. Takže je tvořena nejváženějšími vědci, a ted' také inženýry a výzkumnými pracovníky v lékařství, protože v současnosti k ní patři také Národní akademie lékařských věd (dříve Institute of Medicine) a Národní inženýrská akademie.

Cílem je radit $v$ národních otázkách. Aby národní akademie mohly plnit své poslání, zřídily výkonný orgán, což je právě NRC, která spojuje experty s rưzným 
148 zaměřením - velmi široké sdružení expertů, včetně lidí, jako jsem já, kteří stojí mimo národní akademie. A NRC následně zřizuje rady a komise, které mají hledat odpovědi na otázky federální vlády nebo jiných orgánů. Federální vláda je hlavním zákazníkem. Např́klad zrovna ted' vedu Výbor pro přírodovědné vzdělávání (Board on Science Education). Jeho misí je radit vládě v otázkách vzdělávání v přírodovědných oborech. Výbor byl např́klad odpovědný za rámcovou přípravu struktury, pod níz vznikaly Next Generation Science Standards, nebo za program Taking Science to School zabývající se efektivností přírodovědného vzdělávání na úrovni primárního a nižšího sekundárního vzdělávání. Výbor pod vedením komise, kterou jsem řídil, také vyvinul program Successful STEM ${ }^{1}$ Education, zaměřený na vysoce úspěšné školy a programy. Na tom ukážu, jak NRC funguje.

Projekt, na kterém jsem pracoval, vznikl proto, že se na National Science Foundation (NSF) ${ }^{2}$ obrátil jeden kongresman s požadavkem, aby vytvořila seznam primárních a sekundárních škol, které jsou nejúspěšnější v oblasti vyučování STEM. Jenomže to nebylo něco, co by lidé z National Science Foundation mohli udělat, a tak přišli do NRC a zeptali se nás: „Co máme s tímto požadavkem dělat?“ Tak jsme jim navrhli, že by bylo možné vytvořit seznam kritérií, jejichž pomocí by šlo určit školy a programy, které jsou vysoce úspěšné. Tato zakázka pak byla předána výboru pro prírodovědné vzdělávání, kde jsem byl v té době členem, a požádali mě, abych předsedal komisi, která se touto problematikou zabývala.

DG: Jak dlouho jste se tomu mohli věnovat? Kolik jste dostali času?

AG: To je opravdu dobrá otázka. Obvykle pracují rady odborníků NRC s časovým limitem mezi dvěma až třemi lety...

DG (směje se): To je dost dobré!

AG: To ano, ale $v$ tomto případě? Devět měsíců. Takže to bylo šíleně narychlo. Nemohli jsme si dovolit dlouhé plánování postupu, místo toho jsme svolali workshop. A zatímco jsme čekali, než se workshop uskuteční, tak si ředitele NSF předvolal kongresman, který původně přišel s tím požadavkem. Ten praštil do stolu: „Kde je závěrečná zpráva? Na to, abyste ji udělali, jste měli osmnáct měsíců! Kde je moje zpráva?“ A z ničeho nic $z$ toho byla veřejná událost, $v$ jedněch novinách byl titulek „Poslanec zcupoval ředitele National Science Foundation!“, a to proto, že čekali na mou zprávu. A já říkám: „Osmnáct měsícư? To je proto, že to zabralo hodně času kongresman přišel s požadavkem, NSF musela vymyslet, co s tím může dělat, potom přišli do NRC, my jim řekli, co mohou udělat...“ Tou dobou, kdy vznikla naše skupina, jsme měli už jenom devět měsíců, což je velmi krátká doba. Tak jsme nakonec udělali workshop a vydali zprávu. Ale napsat tu zprávu bylo velmi těžké, protože nemůžete jen tak říct, „je potřeba provést další výzkum“. Což bychom my, výzkumní pracovníci, rádi řekli (směje se). A zároveň nemůžete jít mimo výzkumné doklady ${ }^{3}$ -

Science, Technology, Engineering and Mathematics.

2 Národní vědecká nadace - instituce, která rozděluje granty na výzkum v oblasti prírodních věd a jejich výuky.

3 Termín „evidence“ zde překládáme jako „doklady“, přestože v některých kontextech se užívá i „důkazy“. 
NRC je tak prestižní a důvěryhodný zdroj informací, protože se drží výzkumných

dokladů. Takže jsme potřebovali z výzkumných dokladů vytěžit, co jen šlo, ale nejít za ně. A tak jsme to i udělali. Potom jsme pro NSF uspořádali brífink - a oni byli z té zprávy nadšení. Pak jsem ji dal asistentům kongresmana a ti řekli, že „jsou zklamaní, že je to tak složité“.

Ale to už jsem dřív slyšel a mám na to odpověd' - jistě, je to složité. Kdyby to bylo jednoduché, už bychom to dávno vyřešili. Je to složité, protože je to složitý problém. A tak si tu zprávu odnesli a zamysleli se nad ní a nakonec došli k tomu, že se jim líbí. Uspořádali velkou veřejnou akci, jejímž cílem bylo, aby si kongresman přisvojil za moji zprávu zásluhy, což bylo v pořádku, proti tomu nic nemám. Potom jsem byl předvolán před parlamentní komisi, abych o té zprávě svědčil. A pak další rok přijali zákon, který nařizoval, aby NSF utratila půl milionu dolarů za vytvoření rámce pro měření toho, jestli byla doporučení z mé zprávy zavedená do praxe. Takže jsem předsedal další komisi NRC, která tento rámec připravovala, a NSF uzavřela smlouvu se soukromou organizací, aby vytvořila indikátory, abychom věděli, jestli se klade větší dưraz na obsah vzdělávání, jestli se od předškolního až do 5 . ročníku věnuje více času př́rodovědě, a další indikátory...

DG: A pracuje NRC vždycky na základě požadavků z Kongresu USA, nebo si vytváří vlastní agendu, vlastní témata výzkumu?

AG: Někdy NRC nebo některá z komisí řekne: „Toto je opravdu problém a myslíme si, že by o tom federální vláda měla zjistit víc." Takže potom občas navrhneme některé vládní organizaci nebo soukromým investorům téma, které bychom rádi studovali. Například výzkum výuky př́rodovědy na základních a středních školách, Taking Science to School, byl, pokud se nepletu, z velké části financován soukromými institucemi, možná dokonce kompletně. A i když cílem bylo informovat vládní činitele, zakázka byla hrazena z privátního zdroje. Takže někdy přijde podnět pro výzkumnou zprávu i ze soukromých organizací, někdy od vlády nebo jiných nadací.

DG: $V$ jedné ze svých publikací ř́káte, že se sice zdá, že všichni výzkumníci spolu souhlasí, ale není tomu tak. Např́klad jsou zastánci diferenciace žákủ i jejího zrušení a oba tábory používají jiné argumenty. Ted' ř́káte, že NRC je výzkumná organizace, která se těši mimořádné důvěře. Je tedy ve výzkumu hodně různých názorů, nebo táhnou všichni za jeden provaz? Jakou tedy má NRC roli, je to jeden z mnoha hlasů, nebo je ten nejdůležitější? A poslouchají tento hlas politici?

AG: Řekl bych, že je to jeden z mnoha hlasů, ale je obzvláště důležitý a je to hlas, kterému obvykle naslouchají všechny strany. Výsledky a závěry NRC jsou vnímány jako pocházející od nestranné skupiny expertů. Lidé jsou do komisí NRC vybráni na základě svých dovedností a ochoty zvážit všechny důkazy s cílem vynést opravdu spravedlivý rozsudek. Ti, kdo jsou vybráni, nejsou ostatními vnímáni jako ti, kdo by už předem měli jasná stanoviska. Ne, že by se nikdy $k$ tématu nevyjádřili, ale pokud jste obecně vnímán jako někdo, kdo např́klad otevřeně vystupuje jako zastánce testování, tak pravděpodobně nebudete v odborné komisi pro testování. Takže zprávy NRC jsou hodně respektované, ale rozhodně to není jediný nebo hlavní hlas. A ani to není hlas, který by většina lidí cíleně vyhledávala, protože hodně politiků zná své 
150 rozhodnutí už předem a jenom hledá doklady, které ho podpoří, takže si vyberou bez ohledu na to, co ríká NRC.

DG: Takže se dokonce může stát, že nějaký kongresman požádá o zprávu, ale když je v ní potom nějaký silný závěr, jako třeba „akontabilita na základě testů nefunguje“, tak ji nepoužije? I to se stává?

AG: Ano, to se rozhodně stává.

DG: Chtějí po vás zprávu, ale když se neshoduje s jejich názory a cíli, tak prostě dělají, že neexistuje?

AG: Řekl bych, že když je NRC požádaná o vypracování zprávy, tak jsou zadavatelé obvykle otevřenější tomu, jaké přináší výsledky, než je to $v$ prŕpadě jiných organizací. A pokud tomu otevřeni nejsou, tak je obvykle ani nenapadne o výzkum NRC požádat. Takže $k$ ignorování výsledků, které dodala NRC, možná dochází méně často než v př́padě jiných institucí, protože obrovská řada zpráv byla vyžádána na základě nějakého federálního nebo vládního politického zájmu. Ale rozhodně tomu tak není vždycky.

Uvedu můj oblíbený príklad. Jde o zprávu NRC s názvem Systems For State Science Assessment. Bylo to šetření vedené Markem Wilsonem, statistickým metodologem a odborníkem na prírodovědné vzdělávání z Berkeley. Je to skvělá zpráva, opravdu předkládá model toho, jak nastavit na úrovni celého státu takový systém hodnocení, který by podporoval kvalitu vyučování. Takové hodnocení by mohlo sloužit pro řizení systému, ale současně by podporovalo kvalitní vyučování. A vidíte - ta zpráva je naprosto ignorovaná. Nikdy ji nikdo nepoužil, na žádné úrovni. Nejsem si jistý, kdo ji zadal a financoval - mohli bychom to zjistit, kdybychom se podívali -, ale at' už to byl kdokoli, naprosto ji ignoroval. To je jen jedna část skvělé, ale nevyužité práce této skupiny, které jsem také součástí, Board on Science Education.

DG: Ale alespoň zpráva existuje a výzkumná komunita by na ni mohla navázat a pracovat s ní.

AG: Ano, výzkumní pracovníci o ni projevují zájem, ale pokud jde o dopad na politické rozhodování, vyšla naprosto naprázdno. A je to ještě o to víc do očí bijící vzhledem $\mathrm{k}$ tomu, jak to, podle mě, byla dobrá práce.

\section{Výzkum v resortu ministerstva školství}

DG: Další institucí je potom Institut edukačních věd (Institute of Education Sciences, IES), který je součástí Ministerstva školství USA. Kolegyně Simonová zjistila, že byl založen až $v$ roce 2002 - byla tedy před ním ještě jiná organizace? A proč vytvářet novou instituci, jaký to mělo důvod?

AG: Ano, před IES tu byl Úřad pro výzkum a rozvoj ve vzdělávání (Office of Educational Research and Improvement, OERI). IES byl založen $v$ roce 2002 jako jeho součást. Byl to zákon ${ }^{4}$ přijatý během Bushovy administrativy s cílem zvýšit rigoróznost

4 Education Sciences Reform Act. 
výzkumů vzdělávání pro ministerstvo školství. Velký důraz byl kladen - no, většina lidí by řekla, že čím byl IES důležitý, bylo to, že získával data znáhodněnými experimenty. Ale já jim vždycky vysvětluji, že co bylo ohledně IES revoluční, není důraz na randomizované experimenty, ale zúžení výzkumné otázky. Výzkum ve vzdělávání financovaný ministerstvem školství se nově měl zaměřit pouze na jednu věc - co pomáhá $\mathrm{k}$ zlepšení výsledků. Co ve vzdělávání funguje, a obzvlášt' co funguje pro dosažení lepších výsledků ve vzdělávání. Takže když zúžíte tu otázku na zjišt’ování toho, co funguje, je to potom už jen krůček k tomu, říct, „no, potřebujeme doklady $z$ randomizovaných experimentů “. A to proto, že znáhodněný experiment je nejlepší způsob, jak odhalit vztah mezi pŕícinou a účinkem. Takže nešlo o to, že by IES kladl důraz na randomizované studie, ale na zjišt’ování toho, co funguje. A následkem toho se znáhodněné výzkumy staly mnohem důležitějšími.

IES je ve skutečnosti flexibilnější a zabývá se širšími tématy než jen randomizovanými studiemi, protože žadatelé mohou předložit návrhy, které souvisejí s kterýmkoli z pěti cílů: 1) průzkum již existujících dat pro nalezení korelace, která by mohla vést $k$ hypotéze následně testovatelné rigoróznějšími postupy; 2 ) vývoj postupů k zlepšování výsledků a snižování nerovností, které by následně mohly být otestovány rigoróznějšími postupy; 3) pilotáž účinnosti, tedy randomizované experimenty v menším rozsahu. Čtvrtý cíl je potom ověření efektivity, tedy randomizovaný pokus $v$ plném rozsahu a reálných podmínkách, a pátý cíl je ověření přenositelnosti do praxe. Takže IES je ve skutečnosti bohatší a širší než jen randomizované pokusy, ale všech pět cílů výzkumu IES vede k základní otázce, co funguje.

DG: A IES je tedy organizace, která financuje výzkum, nebo mají také svoje vlastní výzkumné pracovníky?

AG: Ne, je to jen agentura, která financuje výzkumy prováděné jinými.

DG: A jak si daný výzkum vybírá? Stanoví téma, které chtějí zkoumat, a výzkumná komunita pak něco vymyslí a nabídne?

AG: IES je výzkumné oddělení Ministerstva školství USA, takže je to federální agentura, jejímž posláním je rozdělovat finance na podporu výzkumu. Má čtyři sekce - Národní centrum vzdělávací statistiky (National Center for Education Statistics), které obstarává NAEP 5 a sbírá další typy statistik o školství, infrastruktuře a o účasti ve vzdělávání, zkrátka všechny statistiky z oblasti vzdělávání. Pracují tam nějací výzkumní pracovníci a vydávají zprávy, ale ty jsou deskriptivní.

Druhou sekcí je Národní centrum výzkumu ve vzdělávání (National Center for Education Research), které podporuje výzkum ve vzdělávání v tuctu předem stanovených oblastí. 6 Další sekcí je potom Národní centrum výzkumu speciálního vzdělávání

5 The National Assessment of Educational Progress, federální reprezentativní výběrové šetření znalostí a dovedností amerických žáků. (Pozn. red.)

6 Čtení a psaní; efektivní učitelé a efektivní vyučování; kognice a žákovské učení; pedagogické vedení; postsekundární a celoživotní vzdělávání; programy a politiky $v$ oblasti předškolního vzdělávání; sociální a behaviorální kontexty školního učení; vzdělávací technologie; vzdělávání $\checkmark$ oblasti př́rodních věd, technologií a inženýrství, matematiky (STEM); zlepšování vzdělávacích systémů; žáci, pro něž angličtina není mateřský jazyk; speciální témata. Kromě dvanácti věcných témat jde i o rozvoj metodologie pedagogického výzkumu. (Pozn. red.) 
152 (National Center for Special Education Research), které je úplně stejné, jenom jsou všechna témata a sbíraná data zaměřená na speciální vzdělávání.

A čtvrtou sekcí je Národní centrum pro evaluaci vzdělávání (National Center for Education Evaluation), které má pod sebou informační centrum o efektivních programech, regionální vzdělávací laboratoře a navíc uzavírá kontrakty pro evaluaci konkrétních iniciativ. Takže většina lidí, když mluví o IES, má obvykle na mysli Národní centrum výzkumu ve vzdělávání, což je místo, kam jdete, pokud chcete soutěžit o dotace pro podporu výzkumu.

DG: Vy pracujete v národní radě IES. Jaká je role této rady?

AG: Hlavní úkol rady je schvalovat priority IES. To je tedy jedna formální kontrolní funkce, kterou máme. Jak jsem říkal, zaměřují se na dvanáct různých témat a ta my schvalujeme. To se děje formou spolupráce mezi zaměstnanci a radou, a my je nakonec oficiálně schvalujeme. Výzkumné priority se poměrně značně shodovaly v průběhu Bushovy a Obamovy vlády, což je docela neobvyklé, to se v mnoha federálních vládách nestalo. Ale to je částečně dané složením rady a částečně taky, myslím, kontinuitou působení odborných pracovníků IES. Velká změna v prioritách IES během přechodu od Bushovy k Obamově vládě byla, že během Bushovy administrativy vedl IES Russell Whitehurst, který přinesl důraz na rigoróznost. V době Obamovy administrativy bylo IES vedené Johnem Eastonem, který položil důraz na relevanci výzkumů. John Easton pochází z prostředí výzkumných partnerství. Měl zkušenost z vedení Konsorcia pro výzkum chicagských škol a zavedl financování výzkumných partnerství jako součást IES. A kladl mnohem větší dưraz na přínos výzkumu pro politické rozhodování a tvorbu zákonů. Jinak se ale obě administrativy $v$ mnohém shodovaly a navazovaly na sebe. Takže role Národní rady edukačních věd je především ve schvalování priorit, slouží také jako poradce pro rozvoj a řešení překážek v rámci práce IES a navrhuje vedoucí výše uvedených čtyř sekcí. Dále poskytuje konkrétní doporučení Kongresu USA nebo vládě ohledně rízení výzkumu ve vzdělávání a vysvětluje tuto problematiku veřejnosti a získává pro ni podporu.

DG: Takže rada má na starosti spíše výzkum. Jaký je ale vztah mezi vaší radou a tou částí ministerstva školství, která se přímo podílí na politickém rozhodování? Jste vy, nebo rada obecně zváni jako poradci přímo do procesu politického rozhodování a tvorby zákonů, anebo dodáváte výzkumné zprávy? Je nějaké spojení mezi výzkumem a politickým rozhodováním?

AG: V mnoha vládních organizacích jsou výzkumná a rozhodující část od sebe oddělené a je velmi těžké toto oddělení přemostit. Například iniciativa Race To The Top pochází z roviny politického rozhodování. ${ }^{7}$ Když to bylo zavedené, objevil se nápad, že IES tuto iniciativu zhodnotí prostřednictvím Národního centra pro evaluaci vzdělávání. To bylo před několika lety. Od té doby se to nikam nepohnulo. Obecně platí, že mezi výzkumem a politikou není žádné velké propojení. To má ale i svou výhodu, a sice že IES funguje se slušnou mírou samostatnosti. Ředitel IES je jmenován prezidentem, ne ministrem školství, a má určitý stupeň autonomie. Takže to je

7 Viz první část rozhovoru (Orbis scholae 3/16). 
dobrá věc. Na druhou stranu nevýhodou je, že při politickém rozhodování výzkumů nikdo nevyužívá. Toto opravdu není zrovna silná stránka našeho systému a není to problém jenom vzdělávání, je to velmi obvyklé.

DG: A existuje $z$ vašeho pohledu nějaký způsob, jak ty dvě strany propojit? Co můžeme udělat pro lepší vztah výzkumu a politiky?

AG: Ano, určité způsoby existují. Jak jsme na obecné úrovni já a moji kolegové konstatovali: Dosud jsme byli přesvědčeni, že politických rozhodnutí podložených výzkumem dosáhneme šiř̌ením výsledků výzkumu. Musíme se ale posunout ke snaze tvořit výzkumně podložená politická rozhodnutí prostřednictvím trvalé spolupráce. Myslím si, že to platí i v prípadě vzdělávání. Je nedostačující, když výzkumná zařizení, $v$ tomto prípadě IES, provedou výzkum a potom informují politiky o jeho výsledcích. Spíše tu musí být neustálé propojení mezi oběma stranami, což může pomoci, aby politici začali věnovat pozornost výzkumným zjištěním. Ale není to lehké, je to neustálá výzva.

\section{Financování kvalitativního výzkumu a inovací}

DG: Jaká je role kvalitativních výzkumníků? Kvalitativně orientovaní badatelé někdy říkají: „My provádíme výzkum se stejnou měrou pochopení problému a přinášíme stejné množství zjištění, ale nemáme žádnou možnost radit nebo $v$ rámci politického rozhodování provést nějaký výzkum. " Jaký je váš názor - může kvalitativní výzkum radit při politickém rozhodování?

AG: Nemůžete financovat všechno. A zákon Education Sciences Reform Act jako prioritu velmi jasně určil identifikaci programů, které mají jasný př́nos pro zlepšování vzdělávacích výsledků a snižování rozdílů mezi žáky. A to je kauzální otázka. Kvalitativní design může přinést spoustu nových zjištění, ale není vhodný pro zodpovězení kauzálních otázek. Nicméně i v rámci financování ze strany IES je to pro kvalitativní výzkum místo, protože - jak jsem už zmínil - jedním z cílů je tvorba nových programů a zákonů. A získávání informací o tvorbě nových programů často vyžaduje kvalitativní výzkum. Chcete-li pochopit, jak lidé prožívají nové metody, chcete-li porozumět tomu, co si lidé myslí o zavádění nových metod, musíte provést takový výzkum, který pracuje s malým vzorkem, ale jde do hloubky. Proto řada studií, které se zaměřují na tento cíl, mají i kvalitativní součást. Takže kvalitativní výzkum v IES probíhá. I přesto je ovšem hlavní otázka, na kterou hledají odpověd', kauzální, a na to není kvalitativní výzkum dobře vybavený.

Jedna věc ohledně federálního financování výzkumu ve vzdělávání je, že ačkoliv IES může být první místo, kam se pro finance podíváte, výzkum ve vzdělávání je financován i mnoha jinými organizacemi. Velmi významné jsou National Science Foundation (NSF), jejíž ředitelství pro vzdělávání a lidské zdroje financuje výzkum vzdělávání v oblasti STEM, a potom Národní zdravotní ústavy (National Institutes of Health), kde také probíhá spousta výzkumů zaměřených na vzdělávání - obzvlášt' $\checkmark$ př́padě Ústavu pro dětské zdraví a vývoj. Takže IES není jediné místo pro výzkum 
154 ve vzdělávání, NSF také podporuje řadu i kvalitativních výzkumů v oblasti vzdělávání STEM. Jeden z rozdílů mezi OERI, což byl předchůdce IES, a současnou situací, byl odklon od kvalitativního výzkumu ne kvưli nechuti vůči kvalitativnímu výzkumu, ale protože došlo $k$ zúžení výzkumné otázky.

DG: Co je to 13 fond?

AG: Program 13 (Investment In Innovation) byl součástí stimulačního balíčku během ekonomické krize, ale vydržel až doby, kdy děláme tento rozhovor. Byl navržen tak, že jste mohl získat víc peněz, pokud váš projekt byl podpořen silnějšími výzkumnými doklady. Pokud byl váš projekt více explorační, dostal jste méně peněz. Jsou tu tři úrovně. První je přenositelnost. Tato úroveň je pro projekty obsahující velmi silná data z randomizovaných pokusů, která prokazují jeho efektivitu. Původně jste mohl dostat až 50 milionů dolarů, v pozdějších letech, kdy už měli méně peněz, byly granty nižší, ale pořád hodně peněz. Druhá úroveň je validace - projekty, které mají určité množství dat z randomizovaných pokusů, ale ne nijak závratně objemné množství. Tyto validační granty se mohly pưvodně vyšplhat až na 30 milionů dolarů, potom to bylo 20 a 15 milionů. Ale pořád velké granty. A třetí úroveň se jmenuje rozvoj, kde váš projekt obsahoval dobrou logiku, možná nějaká počáteční data, která ho podporovala, ale ne velké množství rigorózních dat. Tyto mohly pưvodně dosáhnout na pět milionů, potom na tři miliony... Pořád velké peníze. A hlavní myšlenka byla nalézt programy, které fungovaly, ověřit je $v$ co nejširším měřítku a zjistit, jak by bylo možné masově zavést je do praxe.

První z těch programů, které úspěšně získaly ty padesátimilionové granty pro šǐření, byly jedny z nejviditelnějších a nejsilněji vnímaných vzdělávacích programů v USA - Success for All, což je reformní program základního školství, který staví na vyučování čtení a matematice $v$ malých skupinách žáků, aby se zajistilo, že získají pevné základy; Teach for America, program, o kterém jste určitě slyšeli a $v$ jehož rámci jsou do škol zváni lidé s dobrými odbornými znalostmi, kteři ale nemají vystudovanou pedagogickou školu a prošli jen letní př́pravou; Reading Recovery, což je program vedení žáků systémem jeden na jednoho a který disponuje nejsilnějšími doklady, které potvrzují jeho efektivitu a schopnost pomoci dětem dohnat ztrátu v učení; a KIPP Academies, což je přistup v rámci hnutí charterových škol, který má také silné doklady své efektivity. U charterových škol některé výzkumy mají pozitivní, jiné negativní výsledky - toto je jeden z těch kladně hodnocených. Tyto programy měly již z minulosti doklady o své účinnosti a dosavadní data z projektu $I 3$ jsou také pozitivní.

Zajímavé ale je, že všechny tyto programy čelily jednomu obdobnému problému, a to faktu, že pro ně bylo obtižné masově se rozširíit. Success for All měl problémy se získáním dostatečného množství škol, které by přijaly jeho př́stup. Program totiž škola zavede jenom $v$ prípadě, pokud pro to bude hlasovat, pokud se nepletu, $80 \%$ učitelů. Takže je těžké takové školy najít. Teach for America měl problém získat potřebné množství mladých, energických, čerstvě vystudovaných lidí, kteří by do programu nastoupili, aniž by zároveň program snižil nároky na ně kladené, což bylo předem zamítnuto. Takže i když máte hodně peněz, není tak snadné tyto programy opravdu rozširíit. 
13 program je jedním z mnoha príkladů, kdy se Obamova administrativa snažila dát důraz na reformy podpořené doklady. Ron Haskins vydal knihu ${ }^{8}$, která uvádí šest takových programů. Haskins navíc pochází z republikánského prostředí, takže je docela dobré, když říká, že Obamova vláda dávala přednost výzkumným dokladům nebo něco $v$ tom smyslu. Mapuje šest př́kladů politických rozhodnutí, která byla založena na dokladech, a naléhá na to, aby $v$ tom pokračovala i další administrativa.

DG: Pokud se vrátíme k IES, jak vypadá typický grant? Sdružují se pro granty IES lidé z celých Spojených států?

AG: Ne, typicky máme výzkumného pracovníka při univerzitě, někdy třeba tři pracovníky, kteří se dají dohromady a o grant soutěží. Mohou být z jedné instituce nebo i z několika, ale nesnažíme se mít nějakou reprezentativní skupinu výzkumných pracovníků. Jedná se o samostatné projekty vycházející z výzkumného programu jednotlivých výzkumníků.

JS: Mezi politickým rozhodováním založeným na dokladech, evaluací a implementací je rozdíl. Jak často je evaluace součástí programu? Kolikrát jsou programy hodnocené?

AG: To je velmi různé. Jedním ze silných aspektů programu $I 3$ je fakt, že každý $z$ vítězů, který zavede nějaký nový př́stup, at' už plošně jako Success for All, nebo $\checkmark$ menším měřítku, jako rozvojové projekty, tady každý má povinnost podstoupit evaluaci. A nejen to, musí mít i posudek nezávislé třetí strany. Takže např́ílad já jsem získal 13 grant na střední úrovni, na úrovni validace, abych zavedl program nazvaný Families and Schools Together, kterým jsem se zabýval už ve svém předchozím výzkumu. Ale můj tým tento výzkum nedělal, protože jsme museli mít třetí stranu, takže jsme uzavřeli smlouvu s americkými výzkumnými instituty (American Institutes for Research, AIR), které potom ten výzkum provedly. A toto je jedna z nejsilnějších stránek programu 13: všechny 13 projekty byly stále hodnoceny. No, a projekty financované $v$ rámci standardní soutěže IES jsou výzkumné studie, takže nejde o hodnocení, je to výzkumný projekt, jde předně o výzkum než hodnocení. Jsou ale i jiné oblasti, kde dochází k evaluaci. Když je do praxe zavedeno federální nebo státní rozhodnutí, někdy je evaluace součástí, jindy ne. Jako výzkumník vždy volám po evaluaci, ale ne vždy k ní dojde.

\section{Soukromé financování pedagogického výzkumu}

DG: Z českého pohledu by se dalo říci „na to jsme př́liš malí“. Takže pokud se podíváte na úroveň států, třeba na Wisconsin nebo New York, jsou tu nějaké stejné výzkumy $v$ menším měřitku, nebo se jen použivají výsledky $z$ federálně dotovaného výzkumu?

AG: Na úrovni států je výzkum financován jen velmi málo. Na lokální úrovni jsou kapacity velice omezené, ale dochází k pozitivnímu vývoji v podobě partnerství mezi

8 Haskins, R., \& Margolis, G. (2015). Show me the evidence: Obama's fight for rigor and evidence in social policy. Washington: Brookings Institution Press. 
156 výzkumem a praxí, což je spolupráce univerzit a školních okresů. Nejlepší příklad, a ten zrovna slaví 25 let existence, je Konsorcium pro výzkum chicagských škol, což je partnerství University of Chicago a státních škol v Chicagu, které je dotované především místními soukromými investory.

Od té doby se takových př́padů po celé zemi objevilo víc než tucet. V New Yorku máme Research Alliance for New York City Schools, v Baltimoru je Baltimore Education Alliance, další je v Houstonu, v Los Angeles, Dallasu, Philadelphii, New Jersey... Je jich spousta po celých USA. Podle mě jsou skvělé, přesně o tomto způsobu zapojení jsme totiž hovořili ve William T. Grant Foundation. Moje kolegyně Vivian Tsengová, která vede naše snahy $v$ této oblasti, psala o politickém rozhodování založeném na dokladech, model 2.0. Přesunujeme se od šiření výsledků k modelu zapojení.

V momentě, kdy výzkumní pracovníci a lidé z praxe spolupracují na dlouhodobém institucionalizovaném základě, dochází k dvěma věcem. Za prvé, výzkum může být společně plánován výzkumníky i praktiky. To potom znamená, že výzkumník se zaměří na otázky, jejichž odpovědi budou relevantní jak pro politiky a jejich rozhodnutí, tak pro využití v praxi. To obrovsky zvyšuje šanci, že bude výzkum využit. Je to vlastně stejný prípad, jako když jste se ptal na NRC. Pokud jsou odpovědi na jejich otázky skutečně užitečné, pak vládní činitelé za NRC přicházejí častěji. To je zřejmě další důvod, proč výzkumy NRC možná vládní politiku ovlivňují více než jiné, kromě nestrannosti a vyhlášené rigoróznosti.

Takže podobně zde máme spolupráci mezi univerzitou a školským okresem - lidé z univerzit se ptají na takové otázky, na které lidé ze školského okresu chtějí odpovědi. Bohužel jinak je typické, že my jako výzkumníci sledujeme vlastní záměry a nebereme $v$ potaz, zda někdo bude mít zájem o výsledky. Druhou zásadní věcí je, že výzkumníci mohou v okresu pomoci vytvořit prostředí založené na dokladech. Doklad či důkaz se tak stávají základním pilířem poznání a jedním ze zdrojů informací, které potom politici zohlední při rozhodování. Víme, že výzkumné doklady nikdy nebudou jediným zdrojem rozhodování, to je vždy ovlivněno politikou, ale jde nám o to, aby byly alespoň součástí diskuse. A pokud je tu dlouhodobý vztah, alespoň je tu pro to větši šance.

Co se týče financování takových projektů, v Nadaci Williama T. Granta se k tomu stavíme jasně. Chceme, aby školské okresy a jejich spolupracovníci, ti, co dávají dohromady výzkumná data nebo spolupráci mezi výzkumem a praxí, soutěžili o finance z federálních i soukromých zdrojů, a aby tak mohli provést výzkumné projekty, ze kterých se oni i další mohou učit. Dále bychom rádi viděli podporu infrastruktury a zaměstnanců od místních soukromých dárců. Takže Nadace Williama T. Granta je součástí asociace podporující newyorské městské školy. A totéž platí také pro Spencer Foundation, Joyce Foundation podporuje chicagské konsorcium, William Penn Foundation podporuje Philadelphia Research Collaborative atd. Takto bychom to rádi viděli financované.

To mě přivádí k tématu soukromého financování výzkumu v oblasti vzdělávání. IES, Národní vědecká nadace, I3 granty jsou samozřejmě zásadní zdroje financování výzkumu v oblasti vzdělávání. Soukromí dárci jsou ale také důležitou součástí 
spektra. Zmínil bych hlavně Spencerovu nadaci, která je plně zaměřena na podporu výzkumu ve vzdělávání, a Nadaci Williama T. Granta, kterou nyní vedu - ta se soustředí na výzkum pomáhající vylepšit životy mladých lidi. Vzdělávání je důležitou součástí života mladých lidí, a tím pádem také našeho portfolia. $V$ obou případech tyto organizace řídí proces podobný tomu na vládní úrovni. Máme volnou ruku ve výběru témat, výzkumní pracovníci nám posílají přihlášky, my je posuzujeme procesem peer review a udělujeme dotace na výzkum.

Jsou i více direktivní organizace. Takové řeknou: „Chceme výzkum, který potvrdí výhody charterových škol.“ Zavolají si výzkumníka a zeptají se ho: „Chcete nám udělat tento výzkum?“ Takže jsou direktivnější. Některé z nich jsou obrovské, například Walton Foundation.

V̌̌ichni soukromí dárci jsou zastíněni Bill \& Melinda Gates Foundation, která rozdělí nějaké čtyři miliardy dolarů ročně, z čehož jen zlomek jde na vzdělávání v USA, ale $i$ to je značná částka, kterou věnují na výzkum $v$ oblasti vzdělávání v USA. Zásadním činem Gates Foundation je projekt Measures of Effective Teaching. Byla to studie vedená harvardským ekonomem Thomasem Kanem s cílem rozpoznat a měřit efektivní vyučování. Studie vycházela $z$ předpokladu, že někteří učitelé naučí více než jiní, což je předpoklad vycházející z měření učitelova přínosu do procesu učení prostřednictvím přidané hodnoty. Víme, že přidaná hodnota různých učitelů je odlišná. Proč? Tuto otázku je velice těžké zodpovědět. Studie Measures of Effective Teaching podnikla tisíce videopozorování tř́íd $v$ rozličných městech USA a aplikovala rozmanité typy schémat pro měření průběhu výuky. Potom se testovalo, nakolik tyto různé př́stupy $\mathrm{k}$ měření výuky předpověděly přidanou hodnoty. Badatelé objevili řadu faktorů, které jsou prediktory; ukazatele sice nemohly plně vysvětlit dosaženou přidanou hodnotou, ale významně k tomu přispěly. A data $z$ tohoto výzkumu jsou ted' př́stupná nové analýze, a tak se jedná o jeden z nejvýznamnějších zdrojů dat pro výzkumníky $v$ oblasti efektivity učitelů.

DG: V naší zemi máme čím dál více filantropů i celých organizací a soukromých spolků dotujících programy napríklad $v$ oblasti nerovností, ale nikdy - nebo téměř nikdy - nefinancují výzkum. Mnohým se peníze pro výzkumné pracovníky zdají vyhozené, podporují spíše prímo školy a projekty v nich. Čím to je, že u vás soukromí dárci věnují pozornost i výzkumům?

AG: V naprosté většině také dotují praxi, programy, služby, ale ne výzkum. Ale jak jsem ř́kal, jsou tu i takové organizace, které výzkum podporují. Nadace Williama T. Granta nebo Spencerova nadace se zaměřují přímo na výzkum, další nadace (Gates, Walton, Arnold, Raikes, Ford) zase podporují výzkum pro získání informací o svých investicích a programech. Takže si myslím, že spousta nadací chápe, že výzkum může pomoci v rozhodování, a samy zadávají takový výzkum, který jim v tom pomůže. To je podle mě významná součást fungování nadací v USA. 


\section{Nadace Williama T. Granta}

JS: Každý prezident či prezidentka přinesli něco svého do fungování Nadace Williama T. Granta. Jaké jsou cíle vašeho prezidentství?

AG: To je skvělá otázka. Mám asi dva cíle. Za prvé - pokračovat v zaměření na pochopení role, kterou hrají výzkumná zjištění při rozhodování o politikách zasahujících do života mladých lidí. Za druhé - iniciace programů, politických rozhodnutí a praktických metod, které snižují nerovnosti mezi mladými lidmi. Oba dva jsou podle mě zásadní. Užívání výzkumných dokladů probíhá nějakých pět let, vlastně se ted' učíme $z$ toho, kam jsme se dostali, a hledáme, kam jít dál. Chceme se také soustředit na sběr výzkumných zjištění o tom, jaké podmínky podporují uživání dokladů v politickém rozhodování, a na kvantitativní testy hypotéz o těchto podmínkách. Očekávám, že to bude $v$ budoucnu náš směr. Myslím, že je stále jasnější, že výzkum může pomoci nalézt efektivní př́stupy, ale zároveň je jen velmi vzácně součástí debaty. A z toho důvodu je důležité lépe porozumět, jaké jsou potřebné podmínky pro takový výzkum, který může zlepšit sociální politiku ve Spojených státech. Myslím, že William T. Grant Foundation bude zásadní součástí tohoto procesu.

Prezident Obama prohlásil, že nerovnost je nejzásadnější výzvou současné doby, a v Nadaci Williama T. Granta jsme postupně došli ke stejnému závěru. Když jsem byl v červnu 2013 vybrán jako další prezident, měl jsem možnost mluvit s naší správní radou o třech výzvách. Jednou je rostoucí diverzita $v$ americké společnosti, rostoucí nerovnost a její rostoucí dopady na životy mladých lidí. Druhou jsou změny $v$ technologiích, které mění způsob, jakým jsou poskytovány služby pro mladé lidi, i možnosti, jak provádět $v$ této oblasti výzkum. Třetí je napojení na federální podporu výzkumu. Toto byly základní problémy.

Správní rada nejvíce zareagovala na ten první, a tak jsem se na něj soustředil a v řijnu 2013 jsem za nimi přišel s nápadem, jak vylepšit výzkum prostředí, kde se vyvíjejí mladí lidé, a zaměřit se na konkrétní problém - nerovnost a určení nejlepší reakce na nerovnost. Několik měsíců jsme tento přístup ladili a v únoru 2014 jsme tento program uvedli v platnost, přičemž první sada zahrnovala tři granty: Jeden je pro NRC, aby vytvořil systém pro sledování rovného př́stupu ke vzdělávání ve Spojených státech. Druhý je pro profesora Bruce Bakera, který sestaví celostátní databázi nerovnosti ve financování školství, což je jeden ze zásadních aspektů nerovnosti ve vzdělávání v USA. Třetí je pro trojici ekonomů pod vedením Michaela Lovenheima na University of Michigan pro sestavení konkrétních programů stipendií pro děti s vynikajícím prospěchem, které pocházejí ze sociálně slabých rodin, aby mohly studovat na elitních univerzitách $v$ Texasu. Takže tady máte směs základní práce $s$ daty a přirozeného experimentu. Doufám, že se takovéto projekty budou množit a nám se podaří nacházet inovativní cesty $\mathrm{k}$ snížení nerovnosti. První tř̌ granty směřují do oblasti vzdělávání a já očekávám, že vzdělávání bude jistě velkou částí toho, čím se budeme zabývat, ale nebude to to jediné. 
Zadali jsme čtyři studie, abychom pomohli nastartovat nový výzkum $\vee$ redukci

nerovnosti mezi mladými lidmi. Jedna je o postsekundárním vzdělávání pracovní síly, druhá se týká soudních a vězeňských systémů, což je nyní v USA velké téma, třetí se zaměřuje na imigraci dětí a rodin, čtvrtá je z oblasti péče o duševní zdraví mladých lidí. Doufám tedy, že vzdělávání bude jednou, ale ne jedinou z našich domén, ve které podpoříme výzkum s cílem snižování nerovností.

\section{Použitelnost zahraničních zkušeností}

DG: Bylo velmi hezké slyšet tyto informace o probíhajících výzkumech v USA a částečně také smutné se dozvědět o jejich nedostatečném využití při politickém rozhodování, ale taková je realita všude. Podívejme se na to z pohledu naší malé země, kde vlastně skoro žádný výzkum neprobíhá a kde jsme zvyklí přejímat poznatky zvenči - z USA, Velké Británie, někdy z Německa či Francie, ale to ještě omezeně. Jaké jsou výhody užití výsledků zvenčí a co bychom měli udělat v naší zemi, abychom měli více výzkumu? Nebo můžeme spoléhat na výzkum odjinud, když jde o oblast vzdělávání silně ovlivněnou kulturními specifiky v každé zemi?

AG: Výzkum provedený $v$ jiném kontextu je relevantní, ale nemůže být bezmyšlenkovitě přijímán $v$ novém prostředí. Takže když použijete výzkum provedený ve Velké Británii, musíte vzít v potaz, $v$ jakém kontextu byl uskutečněn tam, jak se to liší zde, co můžeme očekávat, když jej provedeme tady, co musíme vzít v úvahu, pokud ho chceme zde úspěšně aplikovat. Např́klad velikost tř́dy. V USA se ukázalo, že $v$ základním vzdělávání vedou malé třídy $\mathrm{k}$ lepším výsledkủm. Jsou ale země, kde jsou třídy obrovské a dosažené výsledky výborné. Je tedy zřejmé, že kontext je rozdílný a není možné ho prostě přenést jinam. Diferenciace je další z př́kladů. Poznatky o výhodách a limitech rušení diferenciace $v$ USA by zde byly jistě informativní, ale dynamika segregace je $v$ České republice jiná, dynamika umist'ování žáků a učitelů do škol a žáků do tř́i je jiná. Musíte proto zvážit, jak tyto kulturní a strukturální rozdíly mohou vytvářet další rozdíly a ovlivnit vaši práci. Ale úplně bych to nezatracoval. Neřekl bych, že proto, že výzkum proběhl v USA nebo ve Velké Británii, nemá zde význam. Má určitý význam, přinejmenším slouží jako odrazový můstek. $\mathrm{Z}$ něj potom musíte pokračovat $\mathrm{k}$ uskutečnění místního výzkumu, abyste otestovali různé metody jeho implementace právě zde. Myslím tedy, že pokud se zaměříte na výsledky výzkumů odjinud, posílíte zaměření na výzkum ve vašem vlastním kontextu. Naivně si můžete říci, „dělat zde nemusíme nic, prostě použijeme výsledky odjinud“, ale opak je pravdou. Čím více se totiž soustředíte na výzkum jinde, tím spíše ho musíte provést zde, abyste zjistili, jak jej uvést do praxe takovým způsobem, který vám bude vyhovovat.

DG: A myslím, že váš popis americké situace nám také pomůže v rozhodování, z jakých výzkumných studií vybírat a kterým věřit. Pochopíme, kdo se na nich podílel a odkud pocházejí, zda a jaký výzkum z USA potřebujeme. Za to vám velmi děkujeme. 